\title{
Low-cost method for quantification of hydrogen and methane in continuous flow bioreactors
}

\section{Método de bajo costo para la cuantificación de hidrógeno y metano en bioreactores de flujo continuo}

ROJAS-ESCOBAR, Silvino $\dagger$, GONZÁLEZ-CONTRERAS, Brian, JARAMILLO-QUINTERO, Patricia and GUEVARA-GARCÍA, José Antonio*

Universidad Autónoma de Tlaxcala

ID $1^{\text {st }}$ Author: Silvino Rojas-Escobar / ORC ID: 0000-0003-3312-9604, CVU CONACYT ID: 705186

ID $1^{\text {st }}$ Coauthor: Brian, González-Contreras /

ID $2^{\text {nd }}$ Coauthor: Patricia, Jaramillo-Quintero /

ID $3^{\text {rd }}$ Coauthor: Antonio, Guevara-García / ORC ID: 0000-0002-5097-1345, Researcher ID Thomson: Z-3856-2019, CVU CONACYT ID: 204020

DOI: $10.35429 / J R D .2019 .16 .5 .1 .6$

Received October 02, 2019; Accepted November 29, 2019

\begin{abstract}
Bioreactors of industrial scale for gaseous biofuels constitute a field of research worldwide. Automation at a profitable technical and economic level has not been possible because of fluctuating biological systems. The quantification of biogas in continuous flow is difficult to implement by Gas Chromatography and it is very expensive in account of special sensors. In this work, we developed a system with MQ8 hydrogen and MQ4 methane sensors, used in the detection of industrial leaks, for the determination of gas concentration. The sensors were installed on Arduino cards and programmed to plot the concentration in real time. Calibration curves were made for these sensors making use of a standardized mixture of gases, in hermetic jars of known volume. The result is exponential and reproducible, and when using real biogas samples, no problems of interference with other gases are observed. The prototypes are very low cost with respect to the GC equipment and can be installed at the gas outlet of bioreactors with a mechatronic system that allows the monitoring of the composition in real time, which will allow to obtain microbial kinetics in semi-continuous flow in a very economical way.
\end{abstract}

Sensors, Hydrogen, Methane, Economical, Bioreactors, Continuous Flow

\begin{abstract}
Resumen
Biorreactores de escala industrial para biocombustibles gaseosos es un campo de investigación a nivel mundial. La automatización a un nivel técnico y económico redituable no ha sido posible por tratarse de sistemas biológicos fluctuantes. La cuantificación de biogas en flujo continuo es difícil de implementar por Cromatografía de Gases y muy caro a partir de sensores especiales. En este trabajo se desarrolló un sistema con sensores MQ8 de hidrógeno y MQ4 de metano, utilizados en la detección de fugas industriales, para la determinación de la concentración. Los sensores se instalaron en tarjetas Arduino y se programaron para trazar la concentración en tiempo real. Se realizaron curvas de calibración para estos sensores utilizando una mezcla estandarizada de gases, implementando la medición en frascos herméticos de volumen conocido. La respuesta es exponencial y reproducible, y al utilizar muestras de biogás reales, no se observa problemas de interferencia con otros gases. Los prototipos son de muy bajo costo con respecto al equipo de CG y pueden instalarse a la salida de gas de los biorreactores, con un sistema mecatrónico que permita el seguimiento de la composición en tiempo real, lo cual permitirá obtener cinéticas microbianas en flujo semicontinuo, de manera muy económica.
\end{abstract}

Sensores, Hidrógeno, Metano, Económico, Biorreactores, Flujo Continuo

Citation: ROJAS-ESCOBAR, Silvino, GONZÁLEZ-CONTRERAS, Brian, JARAMILLO-QUINTERO, Patricia and GUEVARA-GARCÍA, José Antonio. Low-cost method for quantification of hydrogen and methane in continuous flow bioreactors. Journal of Research and Development. 2019 5-16: 1-6

\footnotetext{
* Correspondence to Author (Email: joseantonio.guevara@uatx.mx)

$\dagger$ Researcher contributing as first author.
} 


\section{Introduction}

A new way of acquiring equipment is rapidly expanding in the scientific community, this is the so-called DIY (Do It Yourself), which provides at least two great benefits: 1) Flexibility, whereby scientists can build just what they need to automate their particular laboratory processes, rather than buying a standard configuration; 2) Economic advantage: commercial equipment that can cost USD $\$ 100,000$ or more, scientists can build it for USD $\$ 5,000$ or less, depending on the desired performance, controls and sensors (May 2019). The same goes for electronics. Instead of building complicated circuits from scratch on a "board," scientists can turn to open source tools, such as the Arduino (2019) programmable circuit board, to design, build and code the necessary controls. In addition, scientists frequently provide detailed guides to assemble created devices and instructions to automate and customize it.

In this way, equipment as sophisticated as an Evolver, a millifluidic module that allows the routing of multiplexed media, the cleaning, transfering from vial to vial and automatic coupling of microbiological strains (Wong et al. 2018) is now available at a low cost, or a Microplate Reader, which is a microplate reader for multiplexed spectrophotometric measurements that performs complete absorbance spectra and fluorescence emission detection, optogenetic stimulation in situ and facilitated programming via touch screen for automated analysis (Szymula et al. 2018); or building a 3D printer for multiple uses (Silver 2019).

Experimental bioreactors for hydrogen and/or methane gas production can be operated in batch or continuously, for periods of 2 to 6 months, with hydraulic retention times ranging from hours to several days, with monitoring of the kinetics of biomass growth and gas production, $\mathrm{pH}$ and temperature control, and the most frequent analysis of organic load, volatile organic acids, COT, NT, COD, BOD, and, of course, the composition of biogas (Montiel Corona et al. 2015). The automation of these processes is a gigantic challenge. In particular, the analysis of biogas composition is carried out by Gas Chromatography (GC), a device that must be turned on and stabilized for a couple of hours, and another couple of hours, passing gas, before shutting it down; so it cannot be used continuously.
Currently, commercial gas sensors are available for online use, integrated into expensive fully automated bioreactors, or separately, but with impractical concentration intervals and no possibility of communication and automation.

On the other hand, there are low-cost semi-industrial gas sensors, which are coupled to Arduino plates, the purpose of which is leak detection, so they are calibrated to respond to low concentrations.

In particular, our interest is focused on the MQ4 sensor, for methane, and the MQ8, for hydrogen, from Zhengzhou Winsen Electronics Technology Co., Ltd. (the technical characteristics are summarized in Table 1).

This paper addresses the adaptation and calibration of these sensors to be used in the determination of the $\mathrm{H} 2$ and $\mathrm{CH} 4$ gas content in the biogas production line of continuous experimental bioreactors which are still in the research and development stage.

The objective was to investigate the sensitivity of these sensors to gaseous mixtures of different composition to determine the existence of a differentiated response and the type of behavior observed; proceeding then to the adaptation of the sensors to the bioreactor and to its calibration, to reach the goal of generating low cost technology for the determination of biogas composition in line and in continuous flow.

\begin{tabular}{|l|l|l|}
\hline \multicolumn{2}{|c|}{ MQ4 } & \multicolumn{1}{c|}{ MQ8 } \\
\hline $\begin{array}{l}\text { Detecting } \\
\text { concentration } \\
\text { scope }\end{array}$ & $\begin{array}{l}200-10000 \mathrm{ppm} \\
\mathrm{CH} 4, \text { natural gas }\end{array}$ & $\begin{array}{l}100-10000 \mathrm{ppm} \\
\text { Hydrogen }\left(\mathrm{H}_{2}\right)\end{array}$ \\
\hline $\begin{array}{l}\text { Sensing } \\
\text { Resistance }\end{array}$ & $\left.\begin{array}{l}10 \mathrm{~K} \Omega-60 \mathrm{~K} \Omega \\
(1000 \mathrm{pm} \mathrm{CH}\end{array}\right)$ & $\begin{array}{l}10 \mathrm{~K} \Omega-60 \mathrm{~K} \Omega \\
(1000 \mathrm{ppm} \mathrm{H})\end{array}$ \\
\hline Using Tem & $-10^{\circ} \mathrm{C}-50^{\circ} \mathrm{C}$ & $-10^{\circ} \mathrm{C}-50^{\circ} \mathrm{C}$ \\
\hline $\begin{array}{l}\text { Circuit } \\
\text { voltage }\end{array}$ & $5 \mathrm{~V} \pm 0.1 \mathrm{AC} \mathrm{OR} \mathrm{DC}$ & $5 \mathrm{~V} \pm 0.1 \mathrm{AC}$ OR DC \\
\hline $\begin{array}{l}\text { Heating } \\
\text { voltage }\end{array}$ & $5 \mathrm{~V} \pm 0.1 \mathrm{AC} \mathrm{OR} \mathrm{DC}$ & $5 \mathrm{~V} \pm 0.1 \mathrm{AC}$ OR DC \\
\hline
\end{tabular}

Tabla 1 Características Técnicas de los sensores MQ4 y MQ8 empleados en esta investigación ${ }^{1}$.

Source: Technical Data. Hanwei Electronics; www.hwsensor.com 


\section{Methodology}

Devices for MQ4 and MQ8 sensors. Glass jars of $1 \mathrm{~L}$ capacity were adapted with a screw cap with two holes both sealed with silicone, one through which the cables connecting the sensor are introduced and another that was conditioned with a rubber setpoint where the gas samples enter, assisted with a syringe of $3 \mathrm{~mL}$ capacity to which three-way valves were adapted for easy handling (Figure 1a). Connections, tubing, 3step wrenches, latex balloon, 1, 3, 5, $60 \mathrm{~mL}$ syringes.

Arduino programmable circuit board. It consists of a board based on the ATmega328P microcontroller. It has 14 digital input/output pins (of which 6 can be used as PWM outputs), 6 analog inputs, a $16 \mathrm{MHz}$ quartz crystal, a USB connection, a power jack connector, terminals for ICSP connection and a restart button. The Arduino-Uno board was connected to the computer using the USB port, while the analog input $\mathrm{A}_{0}$, the output of the $5 \mathrm{~V}$ source and the GND were connected to the sensor as shown in Figure 1b.

Excel interface. This was used as a data acquisition system.

Laptop. A Gateway NV59C laptop with core PLX-DAQ V2 (2014) was used, which is a complement to Excel i5.

Cylinder with 3-component mixture: $50 \%$ hydrogen $/ 40 \%$ methane $/ \mathrm{CO}_{2}$ balance; with Gravimetric Analysis traceable to the CENAM weight frame. INFRA brand. $1 \mathrm{~m}^{3}, 2015$ Psig.

\section{INFRA $\mathrm{N}_{2}$ cylinder}

Bioreactor for biogas generation. We used a glass jar with a screw cap of $6.6 \mathrm{~L}$ capacity with three-way valves adapted for gas collection. Hydrogen production was carried out using sludge from a biological wastewater treatment plant.

The sludge was previously treated by thermal shock. As a substrate, waste from the dairy industry was used, in a procedure described above (Rojas Escobar et al. 2018). On average the reactor produces $1.7 \mathrm{~L}$ biogas/week.
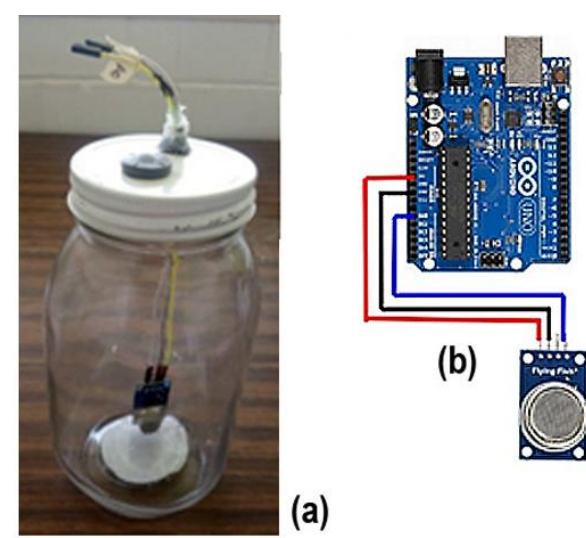

(b)

(a)

Figure 1 Images corresponding to the experimental devices: (a) Biogas composition monitoring chamber; (b) Arduino card and sensor connection

\section{Experimental development}

Using the arduino environment, the programming for the measurement of hydrogen and methane gas concentration was performed, respectively, using the analog input $\mathrm{A}_{0}$, sending the signal to the Laptop through the Arduino serial communication interface at intervals of one second for each reading.

This program was compiled and its execution began. To achieve a real-time graph, the connection to the interface for Excel PLXDAQ V2 was made for data acquisition. The programs and the Excel workbook are available upon request to the authors.

A $3 \mathrm{~mL}$ syringe was fitted with a threeway valve, a balloon was adapted to one of the valve's outlets as a means of temporary gas storage, a dermal needle was placed on the third outlet.

The balloon was filled with the mixture of hydrogen gas, methane and commercial $\mathrm{CO}_{2}$, purchased from the INFRA company, the dermal needle was introduced through the rubber setpoint in the monitoring chamber and $0.5 \mathrm{~mL}$ doses of gas were applied, obtaining the data in an Excel sheet and graphing simultaneously for interpretation (Figure 2).

This procedure was repeated with methane gas and with biogas from the reactor, with both MQ4 and MQ8 sensors. 


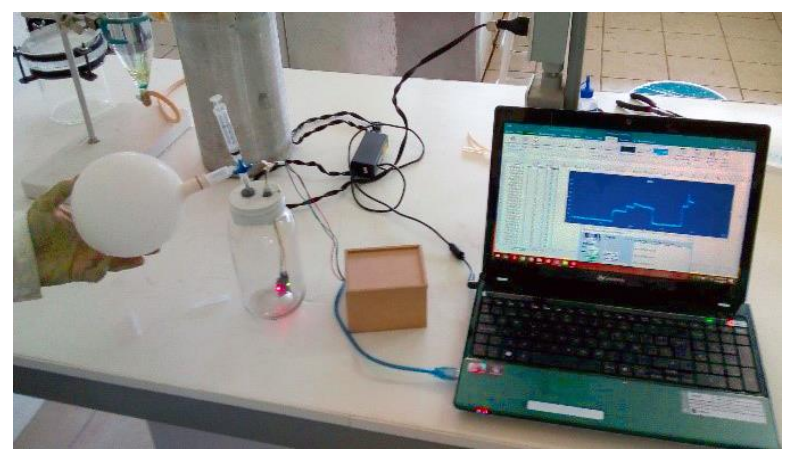

Figure 2 Experimental device for calibration of the MQ4 and MQ8 sensors. The cylinder behind the sensor bottle is that of the mixture of $\mathrm{H}_{2}, \mathrm{CH}_{4}$ and $\mathrm{CO}_{2}$

\section{Results}

MQ8 sensor behavior. In order to observe the sensitivity and behavior of this sensor, doses of different volumes were injected into the monitoring chamber, determining the range of working concentrations.

Subsequently, to establish whether the sensor can be used continuously, in the permanent presence of $\mathrm{H}_{2}$, and to see if there is a differentiated response at different concentrations, the injection of gaseous mixture dose was performed every 30 seconds and consecutively increasing the injected volume. In Figure 3 there is a differentiated response, but that it does not return to the baseline after each pulse, in addition to the fact that the accumulation of $\mathrm{H}_{2}$ in the chamber causes a saturation effect in the sensor.
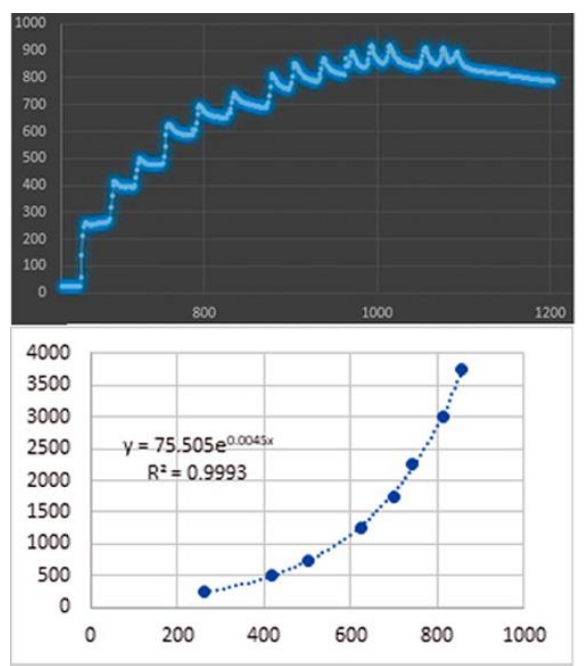

Figure 3 Above: Response of the MQ8 sensor to 3 consecutive doses $(0.5,1.0,1.5,2.0,2.5)$ of the gas mixture $\left(50 \% \mathrm{H} 2+40 \% \mathrm{CH}_{4}+10 \% \mathrm{CO}_{2}\right)$ every $30 \mathrm{~s}$. The $\mathrm{x}$ axis is the time (s), the $\mathrm{y}$ axis are arbitrary units. Below: Graph of response to sensor concentration. The $\mathrm{x}$-axis are arbitrary units, the y-axis is ppm of $\mathrm{H}_{2}$
The response graph of the MQ8 sensor is exponential, with an $\mathrm{R}^{2}=0.9993$ for the first 8 points (maximum concentration of $\mathrm{H}_{2}$ before saturation $=3750 \mathrm{ppm}$ ). The following points are aberrant, due to saturation. This result is conclusive in the sense that the response and sensitivity are excellent, but the sensor cannot be used under conditions of permanent exposure to $\mathrm{H}_{2}$.

After these experiments, the conditions for the sensor to return to the baseline and the optimal time to perform gas measurements were tested.

Saturation of the monitoring chamber with $\mathrm{N}_{2}$ gas was tested, immediately after a pulse of mixed gas to return to the baseline, but it was not possible; instead, after opening the bottle and ventilating with air for approx. 10 minutes, the sensor returned to its baseline (see Figure 4).

Finally, the device was used to determine the proportion of $\mathrm{H}_{2}$ in the biogas produced by a hydrogen generator bioreactor.

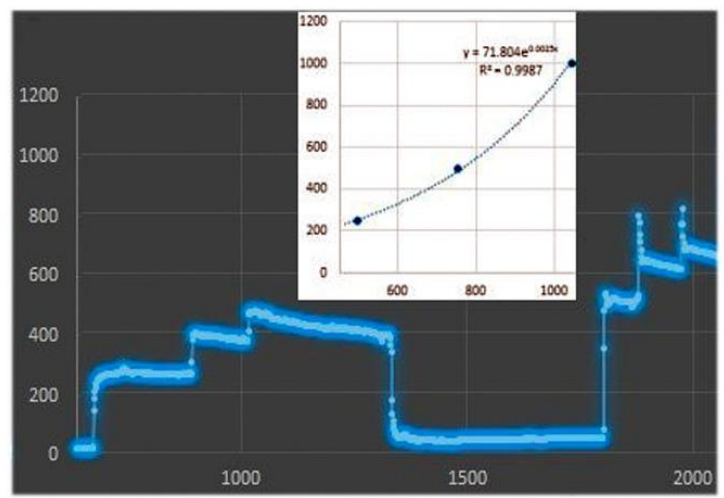

Figura 4 Use of the MQ8 sensor to determine the concentration of $\mathrm{H} 2$ in a biogas sample. The first three pulses are from the bioreactor gas sample, then there is a period of 10 minutes before the injections of the gas mixture $\left(50 \% \mathrm{H}_{2}+40 \% \mathrm{CH}_{4}+10 \% \mathrm{CO}_{2}\right)$. The $\mathrm{x}$ axis is the time (s), the y axis are arbitrary units. The calibration calibration chart is shown on the insert

Figure 4 shows the result of one of these tests. $1 \mathrm{~mL}$ of biogas was injected three consecutive times, then the bottle was opened to return to the baseline and then three $0.5 \mathrm{~mL}$ injections of the gas mixture were made for calibration.

With this procedure, the calibration was $\mathrm{R}^{2}=0.9987$ and the concentration calculated in the biogas was $23 \% \mathrm{H}_{2}$. This concentration is like the ones found in biogas produced in similar bioreactors (Montiel Corona et al. 2018). 
MQ4 sensor behavior. The previous tests were repeated with the MQ4 sensor. Similar to the MQ8 sensor, the MQ4 is a sensor that saturates at a certain concentration. It returns to the baseline faster than the MQ8, but, in the same way, its continuous exposure to biogas containing methane was not possible.

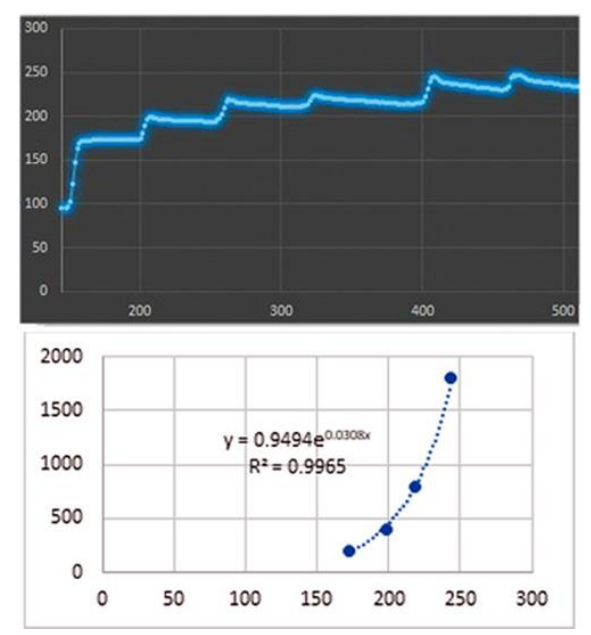

Figure 5 Above: Response of the MQ4 sensor to 2 consecutive doses $(0.5,1.0,1.5)$ of the gas mixture $(50 \%$ $\mathrm{H}_{2}+40 \% \mathrm{CH}_{4}+10 \% \mathrm{CO}_{2}$ ) every $30 \mathrm{~s}$. The $\mathrm{x}$ axis is the time (s), the y axis are arbitrary units. Below: Graph of response to sensor concentration. The $\mathrm{x}$ axis are arbitrary units, the $\mathrm{y}$ axis is ppm of $\mathrm{CH}_{4}$

Figure 5 shows the calibration of the MQ4 sensor with the gas mixture. After calibration, $1.5 \mathrm{~mL}$ of biogas was injected three consecutive times, to determine the concentration. In the case of methane, the composition yielded $52 \%$.

In this way, it was determined experimentally that the reactor is producing more methane gas $(52 \%)$ than hydrogen $(23 \%)$, therefore, methanogenic bacteria predominate over the hydrogen and it will be necessary to apply an extra thermal shock to eliminate methanogenic bacteria. A result obtained in less than an hour, which would have been previously obtained after several days, after sending the corresponding samples to a laboratory with a GC devise.

It is important to mention that $\mathrm{H}_{2}$ gas interference tests were performed on the MQ4 sensor and for methane gas on the MQ8 sensor. No test response of the sensors was observed, so it can be ensured that there is no influence of other gases in the mixture, according to the signal of both sensors.
It is noteworthy that much of the research for the production of methane and hydrogen is based on the design of the fermenter (Izurieta 2019), on the use and/or combination of different types of substrates (González \& Suárez, 2019; Luque 2019), or the optimization of the substrate components (García 2019); however, there is no reference to the optimization of the gas measurement system, a situation that is of paramount importance to minimize process costs and timely monitoring of the process.

\section{Conclusions}

This paper presents for the first time the use of the MQ8 methane and MQ4 hydrogen sensors, of semi-industrial use for leak detection, for the determination of the composition of these gases in line and semi-continuous in production bioreactors of biogas. In both cases, a differential response to the concentration was observed exponentially, with $\mathrm{R}^{2}$ of up to 0.9993 , in a suitable concentration range before saturation of the sensor. In the case of MQ8, the frequency of the biogas pulses it can receive is up to 10 minutes, to return to the baseline; this prevents the sensors from being used continuously but opens the possibility of performing compositional analysis every 10 minutes, throughout the day, which is impossible with a GC devise. This work also contributes with key technology to the growing community of open source hardware oriented to biotechnology, the progress of which is facilitated by the ability to create prototypes, low-cost electronics, optoelectronics and microcomputers in a fast way.

\section{Acknowledgments}

To the General Directorate of Higher University Education of the SEP, for the support through the CA Strengthening Project, 2018 call: "Production of hydrogen and methane from deproteinized whey in a two-stage process to maximize energy recovery and removal of organic matter," from the CA "INTERDISCIPLINARY DEVELOPMENT OF TECHNOLOGIES, PROCESSES AND VALUATION OF WASTE," code UATLXCA-234.

To the members of the support team in Computing and Electronics: M.C. Alberto Nava Saldaña and students Doris B. Tlapalamatl García and José Manuel Arroyo Cruz. 


\section{References}

Arduino (2019). Official site https://www.arduino.cc/

García, B.M. (2019) Efecto de la Disminución de Compuestos Fenólicos de Vinazas Tequileras sobre la Producción de Hidrógeno. Tesis Maestría en Ciencias de la Innovación Biotecnológica. CIATEJ, Mexico.

González, C.J.A., Suárez, M.F. (2019) Potencial de producción de biometano y biohidrógeno a partir de residuos agrícolas: Mucílago de café y cacao y estiércol de cerdo. Tesis Ingeniero Ambiental. Universidad Santo Tomás. Colombia.

Izurieta, M.E. (2019) Estudio de Reactores de Canales Paralelos para la Producción de Hidrógeno a partir de Etanol. Tesis Doctor en Ingeniería. Universidad Nacional de Sur. Bahía Blanca, Argentina.

Luque, P. E.B. (2019) Producción de Hidrógeno mediante Co-Digestión de Biosólidos y Vinazas. Master's thesis. Universidad de Cádiz, Spain.

May M. (2019). Automated science on a shoestring. Nature. 569, 587-588.

Montiel Corona V, Morales Ibarria M, Revah Moisiev S, Guevara García A. (2015). Producción de hidrógeno por fermentación oscura a partir de residuos vegetales y cascarón de huevo como amortiguador de $\mathrm{pH}$. Chemistry Sciences. 5(2), 1-4.

Montiel Corona V., Razo-Flores E. (2018). Continuous hydrogen and methane production from Agave tequilana bagasse hydrolysate by sequential process to maximize energy recovery efficiency. Bioresource Technology. 249, 334341.

PLX-DAQ (Parallax Data Acquisition tool) software add-in for Microsoft Excel. (2014). Parallax Inc. 599 Menlo Drive, Ste.100, Rocklin, CA 95765 USA. Available at https://www.parallax.com/downloads/plx-daq
Rojas Escobar S., Guevara García J.A., García Nieto E., Jaramillo Quintero L.P., Calvario Rivera C.I. Reducción del impacto ambiental del suero lácteo a través de la producción de biohidrógeno en la región norte de Tlaxcala, México. ID: 217. Huatulco, XL Encuentro Nacional de la AMIDIQ. Oaxaca, May 7 to 10, 2019.

Silver, A. (2019). Five innovative ways to use $3 \mathrm{D}$ printing in the laboratory. Nature 565(7737), 123-124.

Szymula, K.P., Magaraci, S.M., Patterson, M., Clark, A., Mannickarottu, G.S., Chow, Y.B. (2018). An Open-Source Plate Reader. Biochemistry. 58(6), 468-473.

Wong, B.G., Mancuso, C.P., Kiriakov, S., Bashor, C.J., Khalil, A.S. (2018). Precise, automated control of conditions for highthroughput growth of yeast and bacteria with eVOLVER. Nature Biotechnology. 36 (7), 614623. 